\title{
Echa prasowe aktywności ministrów oświaty Bułgarii, Szwecji i Węgier odwiedzających Polskę w 1935 r.
}

\begin{abstract}
Press information on activities of ministers of education in Bulgaria, Sweden and Hungary visiting Poland in 1935

The renascent Polish state was being built in the interwar period (1918-1939), developing its position on all possible levels in the international arena. One of these was education and culture. Poland signed a lot of international agreements in this field. This was connected with visits by our ministerial representatives to other countries and with arranging visits in Poland for guests from different countries. In 1935 three ministers of education from abroad visited Poland: Teodor Radew (Bulgaria), Artur Engberg (Sweden) and Balaint Homan (Hungary). The visit of the first two ministers was connected with the signing of a Polish-Bulgarian and Polish-Swiss cultural agreement. The Hungarian minister of education came to Poland to assess the implementation of the agreement which had been signed between Poland and Hungary a year before.

While staying in Poland, beside official meetings with the president and the ministers of education and foreign affairs, our guests visited different educational institutions in cities such as Warsaw, Krakow, Poznan or Vilnius. The press took a lively interest in those visits, reporting them on an ongoing basis. Apart from news reports, editorials and even articles appeared. These were devoted to some of the educational and cultural issues of our guests' countries.
\end{abstract}

Keywords: minister of education, press, foreign visit, foreign cooperation, Bulgaria, Sweden, Hungary, Poland

Po ponad 120 latach niewoli Polska jako kraj musiała restaurować stosunki międzynarodowe na różnych płaszczyznach: politycznej, gospodarczej czy kulturalno-oświatowej. Nic więc dziwnego, że przedstawiciele polskiego rządu często odwiedzali inne kraje europejskie, jak również często przyjmowali gości zagranicznych w Polsce. Kilkukrotnie gościli w Polsce także ministrowie oświaty, w tym między innymi: Con- 
stantin Angelescu (Rumunia) ${ }^{1}$, Kuno Klebersberg (Węgry) czy Uuno Yrjo Hannakla (Finlandia). Pierwszy gościł w Polsce w 1937 r., drugi w 1931, a ostatni w roku 1938.

Każda z tych wizyt miała podobny cel, którym było podpisanie lub wdrożenie umowy o współpracy kulturalnej, naukowej i artystycznej pomiędzy Polską a państwem, którego przedstawiciel odwiedzał Rzeczpospolitą. Za każdym razem obie strony podkreślały zgodnie rangę tej wizyty i jej ważność dla wzajemnych stosunków.

Szczególny jednakże pod tym względem był rok 1935, kiedy to wizytę w odrodzonym państwie polskim złożyło, w różnym czasie, aż trzech ministrów oświaty państw europejskich. Pierwszy w kwietniu 1935 r. przybył do Polski minister oświaty Bułgarii - Teodor Radew. Dwa miesiące później złożył wizytę szef tegoż samego resortu ze Szwecji - Artur Engberg. W listopadzie kilka dni w Polsce spędził węgierski minister oświaty - Bálint Hóman.

Tego typu wydarzenia nie mogły umknąć uwagi prasie, która niejednokrotnie dość skwapliwie odnotowywała cały przebieg wizyt, wszystkie spotkania, wypowiedzi itd. Program wizyt był podobny i najczęściej wymienieni ministrowie odwiedzali te same miasta: Warszawę, Kraków i Poznań. Węgierski minister gościł także przez jeden dzień w Wilnie. Stąd też szczególnie analizie poddano tytuły prasowe wychodzące w tych właśnie ośrodkach, takie jak: „Kurier Warszawski”, „Ilustrowany Kurier Codzienny”, „Czas”, „Dziennik Poznański” czy „Kurier Poznański”.

Posiłkowano się także innymi periodykami wychodzącymi np. we Lwowie czy w Łodzi: „Gazeta Lwowska”, „Echo” i „Ilustrowana Republika”. W ten sposób można było określić stopnień zainteresowania wizytą w tych miastach, które akurat nie gościły delegacji zagranicznych. Jeśli chodzi o prasę typowo pedagogiczną, to wizyty te odnotowywane były przede wszystkim w „Oświacie i Wychowaniu”, periodyku wydawanym przez Ministerstwo Wyznań Religijnych i Oświecenia Publicznego.

Stąd też prasa stała się głównym i zarazem podstawowym źródłem, które posłużyło do analizy przebiegu tychże wizyt. Jak bowiem zauważa Iwona Michalska, opierając się na wcześniejszych badaniach Marcelego Handelsmana i Stanisława Kościałkowskiego, prasa wobec braku innych źródeł staje się ważnym elementem badań nad dziejami oświaty².

\section{Wizyta ministra oświaty Bułgarii Teodora Radewa}

Minister oświaty Bułgarii odwiedził Polskę w dniach 7-12 kwietnia 1935 r. Łódzka „Ilustrowana Republika” zapowiadała tę wizytę następująco: W niedzielę 7 b.m. przybywa do Warszawy butgarski minister oświaty, gen. Teodor Radew. Z okazji pobytu ministra Radewa oraz zamierzonego podpisania umowy kulturalnej polsko-bułgarskiej, prze-

1 Więcej na ten temat: P. Gołdyn, Wizyta ministra oświaty Rumunii Constantina Angelescu $w$ Polsce w 1937 r. w świetle ówczesnych doniesień prasowych, w: Polsko-rumuńskie zwiazki historyczne i kulturowe, red. S. Iachimovechi, E. Wieruszewska-Calistru, Suceava 2013.

2 I. Michalska, Wybrane problemy metodologiczne wykorzystywania prasy jako źródła w badaniach historii wychowania, w: Źródła w badaniach naukowych historii edukacji, red. W. Szulakiewicz, Toruń 2003, s. 127-144. 
widziany jest szereg przyjęć i uroczystości. Minister Radew zatrzyma się w stolicy 3 dni, poczem w dniu 10 b.m. w towarzystwie min. Jędrzejewicza, wyjeżḋa do Krakowa ${ }^{3}$.

„Dziennik Poznański” podkreślał, że mimo iż wizyta ministra Radewa nie zalicza się do tzw. oficjalnych, jest niezwykle ważną z punktu widzenia stosunków polsko-bułgarskich. Stosunki te zaś od początku niepodległości państwa polskiego określano jako pozytywne. Autor tegoż artykułu nazwał Bułgarów „,narodem pobratymczym”. Przy okazji opisał sytuację polityczną, jaka panowała wówczas w tym kraju. W 1934 r. dokonano tam zamachu stanu: przeciwstawiajac się korupcji parlamentarnej i przestarzatym metodom rządzenia, z których korzystały czynniki komunistyczne i rewolucyjne. Minister Radew był członkiem rządu, który został powołany po zamachu stanu w uzgodnieniu z królem Bułgarii Borysem III ${ }^{4}$.

W tym samym artykule zakreślony został cel podpisania umowy kulturalnej z Bułgarią, która przewidywała: wymianę uczniów i profesorów, organizację odczytów $i$ wystaw, stypendia i praktyki. Ten nowy typ umów dwustronnych stworzony zostat przez Polske $i$ oddaje naszej penetracji kulturalnej $w$ dobie kryzysu ekonomicznego, utrudniajacego prywatne kontakty z zagranica, ogromne usługi przez stała pomoc rząów $w$ tej dziedzinie.

O ważności tej konwencji mówił sam Teodor Radew, który w drodze do Polski, w Białogrodzie wydał oświadczenie następującej treści: Jadę do Warszawy w celu podpisania konwencji polsko-bułgarskiej o wspótpracy kulturalnej. Mam nadzieję, że konwencja ta będzie korzystna dla naszych bratnich narodów. Konwencję tę przygotowat mój poprzednik, minister Mołow. Konwencja będzie podstawa wspótpracy nie tylko dla zakładów naukowych, lecz także dla osobistych kontaktów $i$ wzajemnego odwiedzania się przez studentów polskich i butgarskich ${ }^{5}$.

W zakresie kontaktów kulturalnych pomiędzy obu państwami dużą rolę odgrywało Towarzystwo Bułgarsko-Polskie z siedzibą w Warszawie, które z własnej inicjatywy starało się o pozyskanie środków na stypendia dla studentów bułgarskich studiujących w Polsce. Z kolei w Bułgarii aktywne były środowiska polonofilskie, między innymi w Warnie, gdzie powstała inicjatywa postawienia pomnika Władysławowi Warneńczykowi, popierana zresztą w Polsce. Była to samodzielna inicjatywa Bułgarów. Spekulowano, że w uroczystości odsłonięcia pomnika weźmie udział minister wyznań religijnych i oświecenia publicznego Wacław Jędrzejewicz. Obiecał on zresztą rewizytę w Bułgarii ${ }^{6}$. Przewidywano także, że w efekcie podpisania umowy powstanie kilka stowarzyszeń polsko-bułgarskich i bułgarsko-polskich o charakterze kulturalnym i naukowym ${ }^{7}$.

Sam przyjazd zrelacjonowano w ten sposób: W niedziele dnia 7 bm. przybyt do Polski na kilkudniowy pobyt butgarski minister oświaty p. gen. Teodor Radew. Na stacji granicznej w Zebrzydowicach powitat p. ministra p. radca dr E. Zdrojewski w imieniu mini-

\footnotetext{
3 Bułgarski minister przyjeżḋa do Warszawy, „Ilustrowana Republika” 1935, nr 96, s. 3.

${ }^{4}$ K. Kordecki, Polska-Bułgarja, „Dziennik Poznański” 1935, nr 83, s. 3.

5 Oświadczenie min. Radewa, „Czas” 1935, nr 98, s. 2.

${ }^{6}$ K. Kordecki, op. cit., s. 3.

${ }^{7}$ Podpisanie polsko-butgarskiej umowy kulturalnej, „Goniec Częstochowski” 1935, nr 84, s. 3.
} 
stra WRiOP oraz sekretarz poselstwa butgarskiego w Warszawie Stoikow. P. min. Radew wagonem salonowym $w$ towarzystwie powyższych osób udat się $w$ dalsza drogę do Warszawy, dokad przybyt o godz. 23.05. Na dworcu oczekiwat p. min. Radewa minister WR i OP p. Wactaw Jędrzejewicz w towarzystwie wiceministrów ks. Żongołowicza i prof. Chylińskiego $i$ wyższych urzędników ministerstwa, członkowie poselstwa bułgarskiego $w$ Warszawie z chargé d'affaires p. Attinowem na czele, zastępca komendanta miasta mjr. Czuruk, przedstawiciele min. spr. zagran. radca Morstin i radca Poniński, prezydium tow. polsko-butgarskiego z prezesem red. Grosternem na czele, oraz przedstawiciele kolonii bułgarskiej. P. min. Radewowi towarzyszy zastępca naczelnika wydziału kultury butgarskiego ministerstwa oświaty p. Pirijow. W dniu jutrzejszym przewidziane sa wizyty min. Radewa u ministra WRiOP Jędrzejewicza, u p. premiera i ministra spraw zagranicznych oraz podpisanie konwencji polsko-bułgarskiej o wspótpracy kulturalnej, poczem p. min. Beck podejmować będzie gościa śniadaniem. W godzinach popołudniowych nastapi zwiedzanie Warszawy, a wieczorem p. min. Jędrzejewicz wydaje obiad, po którym odbędzie się raut ${ }^{8}$.

Pierwszy dzień wizyty rozpoczął się od złożenia wieńca na grobie Nieznanego Żołnierza. W tym akcie hołdu towarzyszył ministrowi Radewowi zastępca naczelnika wydziału kultury bułgarskiego Ministerstwa Oświaty Danko Pirjow. Oprawę tej uroczystości przygotowali żołnierze z 30 p.p. strzelców kaniowskich. Przybywajacego na plac Marszałka Pitsudskiego ministra, orkiestra wojskowa powitała bułgarskim hymnem narodowym. Następnie minister T. Radew po odebraniu raportu od dowódcy 30 p.p.s.k, płk. inż. Janusza Grzędzińskiego, przeszedt przed frontem kompanii 30 p.p.s.k. Podczas składania wieńca orkiestra odegrała polski hymn narodowy. Po wpisaniu się do księgi, min. Radew przy dźwiękach marszu generalskiego przeszedt przed frontem kompanji 30 p.p.sk. $\mathrm{Na}$ Placu Piłsudskiego obecni byli między innymi minister W. Jędrzejewicz i prezes Towarzystwa Polsko-Bułgarskiego - Jan Dębski .

Jeszcze tego samego dnia nastąpiły spotkania oficjalne. Pierwsze $-\mathrm{z}$ ministrem oświaty W. Jędrzejewiczem. Potem Radew spotkał się z premierem Walerym Sławkiem i ministrem spraw zagranicznych Józefem Beckiem. Właśnie w gmachu MSZ nastąpiło podpisanie polsko-bułgarskiej konwencji kulturalnej. Następnie odbyły się spotkania mniej oficjalne, jak śniadanie wydane przez J. Becka na cześć bułgarskiego gościa, zwiedzanie miasta i wreszcie obiad i raut u W. Jędrzejewicza ${ }^{10}$.

W programie znalazły się takie punkty, jak: zwiedzanie lotniska wojskowego (wszak Radew był generałem) w towarzystwie gen. Rayskiego. Z ministrem Jędrzejewiczem odwiedzili kolonię akademicką im. Prezydenta Narutowicza. Po tych wizytach, jak wcześniej wspomniano, odbył się obiad u ministra Jędrzejewicza, w trakcie którego Radew wygłosił przemówienie, w którym podkreślał, że podpisana konwencja o współpracy kulturalnej pomiędzy Bułgarią a Polską jest wynikiem wielowiekowych dążeń do ,zbliżenia rozłączonych Słowian”, ale także rezultatem długoletniej już współpracy polsko-

\footnotetext{
${ }^{8}$ Butgarski minister oświaty przybył wczoraj do Polski, „Ilustrowana Republika” 1935, nr 97, s. 2.

9 Pierwszy dzień pobytu, „Czas” 1935, nr 98, s. 2.

${ }^{10}$ Minister Radew gościem Rządu polskiego, „Dziennik Poznański” 1935, nr 83, s. 3.
} 
-bułgarskiej. Powiedział wówczas również: Przyjechałem do Polski zobaczyć rezultaty tej wspótpracy oraz znaleźć sposoby dla wzmocnienia terenu dla przyszłych wyników. Grób waszego króla, który 500 lat temu padt pod Warna, jest dziś dla nas światynia. Na miejscu tem budujemy mauzoleum, do którego będa przyjeżżali oddawać hołd i Bułgarzy $i$ Polacy. $W$ walce o uzyskanie niepodlegtości Bułgarji, brało udziat bardzo dużo Polaków ${ }^{11}$.

Minister Radew mówił także, że dużą sympatią cieszy się w Bułgarii twórczość Henryka Sienkiewicza, na którego powieściach wychowywały się także pokolenia bułgarskiej młodzieży. Podobnie Władysław Reymont, który był pierwszym przewodniczącym utworzonego w 1921 r. towarzystwa polsko-bułgarskiego. Po tym przemówieniu i toaście na cześć prezydenta I. Mościckiego i ministra W. Jędrzejewicza oraz „za pomyślność narodu polskiego" głos zabrał Jędrzejewicz: mając zaszczyt gościć po raz pierwszy ministra oświaty Królestwa Bułgarji, wspominam z radościa $i$ nie bez dumy, że pierwsza bułgarska szkołę średnia, która w zeszłym stuleciu wydała cały zastęp bojowników za wasza wolność założyli przybysze z Polski, przyjmowani w Bułgarji z nadzwyczajna gościnnością. Umowa z Bułgarją, odpowiadająca potrzebom szerokich kół Bułgarji i Polski, nada wymianie wartości duchowych cechę stałości i planowości, dzięki pomocy ze strony rządu (wymiana profesorów i uczniów, popieranie studiów historycznych, językowych, organizacja wystaw $i$ t.d.). Życzac dalszego rozwoju i pogłębienia przyjaznych naszych stosunków, wznoszę ten kielich na cześć Jego Królewskiej Mości, króla Borysa III, za pomyślność Bułgarji i za pańskie, panie ministrze zdrowie ${ }^{12}$. Minister Radew dodał jeszcze, że współpraca polsko-bułgarska, nie tylko na niwie kulturalnej, swoimi korzeniami sięga roku 1444, czyli czasu bitwy pod Warną. Dodał również, że podpisana tego dnia umowa jest aktem przemyślanym, podyktowanym przez panujące wówczas stosunki. Jest ona aktem urzeczywistnienia idei, która tkwiła w świadomości obu narodów od wielu wieków ${ }^{13}$.

Trzeci dzień wizyty w Polsce upłynął bułgarskiemu ministrowi na zwiedzaniu szkół i zakładów naukowych. Towarzyszył mu w tych czynnościach minister Wacław Jędrzejewicz. Obecni byli również członkowie poselstwa bułgarskiego. Pierwszą placówką, którą odwiedziła delegacja, był Państwowy Instytut Wychowania Fizycznego. Delegacja bułgarska zapoznała się szczegółowo ze strukturą uczelni, a także zaznajomiona została z jej organizacją i zadaniami. Z Bielan minister Radew udał się na ul. Hożą, gdzie zwiedził Państwową Szkołę Techniczną. Szczególnie zainteresowany był takimi wydziałami, jak: samochodowo-lotniczy, lotnictwa i drogowy. Młodzież tej placówki podarowała bułgarskiemu ministrowi wiele pamiątek i eksponatów wykonanych przez nich własnoręcznie. W szkole tej do zwiedzających dołączył także kurator oświaty okręgu szkolnego warszawskiego, Ignacy Pytlakowski. Następnym punktem programu było zwiedzanie Politechniki Warszawskiej. Tu ministrowi Radewowi towarzyszył rektor tej uczelni -

\footnotetext{
11 O ożywienie wymiany kulturalnej polsko-bułgarskiej, „Dziennik Poznański” 1935, nr 84, s. 2.

12 Ibidem, s. 2.

${ }^{13}$ Min. T. Radew w Warszawie, „Kurier Warszawski” 1935, nr 98, s. 3.
} 
Edward Warchałowski. W godzinach popołudniowych delegacja bułgarska wyjechała do Krakowa $^{14}$.

Jeszcze przed wyjazdem do Krakowa minister T. Radew udzielił wywiadu przedstawicielowi Polskiej Agencji Telegraficznej. Zwracał w nim uwagę na więzy sympatii łączące oba narody i na ich podłoże historyczne. Warto w tym miejscu odtworzyć jego treść: Źródła tej sympatii należy szukać w odległej epoce, kiedy król polski Władysław III poprowadził swe własne wojska przeciwko Turkom, by powstrzymać inwazję, zagrażajaca całej Europie. Śmierć tego króla-bohatera w Bułgarii przypieczętowała braterstwo polsko-bułgarskie. [...] Zbliżenie polsko-butgarskie stało się jeszcze ściślejsze w okresie naszego kulturalnego i politycznego zmartwychwstania. Emigranci z Polski wykazali wielka sympatię do Bułgarii. Występowali często w roli obrońców prześladowanych Butgarów. Pośród emigrantów polskich znajdowat się Jez-Miłkowski, który w swych utworach poruszyt tematy, zaczerpnięte z historii bułgarskiej i serbskiej. Najważniejszym faktem $w$ rozwoju zbliżenia polsko-butgarskiego jest udziat $w$ życiu naszego kraju Czajkowskiego. Jako inspektor imperium otomańskiego, Sadyk Pasza (Czajkowski) pracuje nad równouprawnieniem Bułgarów. W Konstantynopolu Czajkowski jako przyjaciel bułgarskich apostołów odrodzenia narodowego, służy im rada $i$ kieruje nimi $w$ walce o ideały narodowe. Kozacy byli tak popularni wśród Bułgarów, że nazwano ich „naszym wojskiem”. Imię Mickiewicza jest ściśle zwiąane z naszym krajem. Spędził on 10 dni w Burgas, gdzie stały wojska Czajkowskiego. W swych wspomnieniach Miłkowski opowiada ze wzruszeniem o udziale kolonii butgarskiej w pogrzebie Mickiewicza. Przyjacielem Bułgarii byt poeta Tadeusz Miciński, bliski przyjaciel naszego poety Renczo Stawejkowa. W ostatnich czasach stosunki kulturalne pomiędzy Bułgaria a Polska rozwijaja się bardzo szybko. Liczne utwory literackie polskie zostały przettumaczone na język bułgarski. Od 1900 r. do 1933 r. 78 utworów literackich będacych dziełem 21 autorów polskich, przyswojono literaturze butgarskiej. Nasze dzienniki zamieszczaja liczne studia z dziedziny sztuki i poezji polskiej. Krótko mówiąc naród polski, czy to pod względem społecznym, politycznym, czy tė̇ pod względem swej literatury byt zawsze dla nas narodem bratnim, któremu dużo zawdzięczamy ${ }^{15}$.

Te słowa potwierdzają wcześniejsze wypowiedzi ministra Radewa o tym, jak ważną jest współpraca polsko-bułgarska. Potwierdzają także fakt, że umowa ta nie była aktem spontanicznym, ale przemyślanym i potrzebnym obu państwom.

W Krakowie przedstawiciele ministerstw oświaty Bułgarii i Polski pojawili się 7 kwietnia, niespełna pół godziny przed północą. Na dworcu powitani zostali między innymi przez wojewodę krakowskiego dra Mikołaja Kwaśniewskiego, prezydenta miasta dra Mieczysława Kaplickiego, rektorów wszystkich krakowskich uczelni oraz kuratora okręgu szkolnego krakowskiego Mariana Godeckiego. Jak zauważył dziennikarz „Ilustrowanego Kuriera Codziennego", Goście bułgarscy zabawia w Krakowie prawdopo-

\footnotetext{
${ }^{14}$ Min. Radew w Polsce, „Kurier Warszawski” 1935, nr 100, s. 3.

15 Ibidem, s. 3.
} 
dobnie dwa dni, poświęcając czas zwiedzaniu zabytków i pamiątek Grodu Piastów i Jagiellonów $w^{16}$.

Dla ministra Jędrzejewicza wizyta w Krakowie miała bardzo przyjemny wydźwięk. Otrzymał on bowiem dyplom honorowego członka Bratniej Pomocy Studentów Uniwersytetu Jagiellońskiego. W uroczystości tej, która odbyła się na „prastarym dziedzińcu arkadowym” Biblioteki Jagiellońskiej, brał także udział minister Radew. Po jej zakończeniu obaj ministrowie wpisali się do księgi pamiątkowej Bratniej Pomocy Studentów UJ, po czym udali się do „najstarszego gimnazjum Polski”, do gimnazjum im. Nowodworskiego przy Placu Groble w Krakowie. Na gości, na dole w gmachu oczekiwali harcerze, zaś na schodach w szpalerze stanęli uczniowie zgrupowani w różnych organizacjach działających w szkole: Czerwonego Krzyża, Ligi Obrony Przeciwlotniczej i Przeciwgazowej oraz Ligi Morskiej i Kolonialnej. Właściwe powitanie odbyło się w auli, w której orkiestra gimnazjalna odegrała hymn Polski. Następnie głos zabrał dyrektor Lewicki, który powiedział między innymi: Wasze Ekscelencje Panowie Ministrowie! Szkoła, $w$ imieniu której mam zaszczyt witać P. Ministra, jest $w$ Krakowie $i$ w Polsce najstarsza szkoła średnia, pracujaca bez przerwy od drugiej połowy XVI wieku. W szeregach wychowanków tej starożytnej szkoły polskiej jest król Jan Sobieski, wielki i wspaniały zwycięzca Turków pod Wiedniem. Dlugi jest szereg znakomitych mężów, którzy wyszli z tej naszej szkoły i których działalność zapisała się na kartach naszej historii. Jest również wśród nich genialny poeta polski Stanisław Wyspiański, który przewidział i przepowiedziat wolność naszego Państwa i stat się dla naszej doby najognistszem stowem - tak jak symbolem czynu jest dla naszego pokolenia Marszałek Pitsudski. Szczęśliwy jestem, Panie Ministrze, że mogę, witajac Pana w murach naszej szkoły, nawiązać do najmilszych osobistych wspomnień, jakie wywieźliśmy z pamiętnej wycieczki naszej do Butgarii $w$ roku 1927. Witając jak najserdeczniej p. Ministra, chylimy jednocześnie czoło przed podziwu godna żywotnościa narodu bułgarskiego, dla którego pragniemy być serdeczny$m i$ braćmi $^{17}$. Na koniec dyrektor szkoły wzniósł okrzyk na cześć narodu bułgarskiego, króla Borysa III oraz ministra Radewa. Po tym orkiestra szkoły odegrała starą pieśń bułgarską „Szumi Maryca”. Minister Radew podziękował i dyrektorowi, i uczniom szkoły za serdeczne powitanie i gościnę. Swoimi słowami minister miał zjednać sobie jeszcze większą sympatię uczniów i nauczycieli szkoły. Chór szkolny odśpiewał dwie pieśni patriotyczne: Wyleć orle i Święta miłości kochanej ojczyzny. Głos zabrał także jeden z uczniów, niejaki Opałek, który prosił ministra Radewa o przekazanie młodzieży bułgarskiej pozdrowień oraz przedstawił ideologię młodzieży polskiej. Obaj ministrowie otrzymali bukiety kwiatów, wpisali się w księdze pamiątkowej. Przyjazna atmosfera sprawiła, że wizyta znacznie się przedłużyła, co zauważył jeden z dziennikarzy: Pobyt pp. ministrów przedtużyt się $w$ gimnazjum nadspodziewanie. W kancelarii gimnazjalnej p. min. gen. Radew, rozmawiajac $w$ języku francuskim, niemieckim i rosyjskim, wdat się $w$ dys-

${ }^{16}$ Min. gen. Radew i min. Jędrzejewicz przybyli do Krakowa, „Ilustrowany Kuryer Codzienny” 1935, nr 102, s. 16 .

${ }^{17}$ Minister bułgarski w najstarszem gimnazjum Polski, „Ilustrowany Kuryer Codzienny” 1935, nr 103, s. 16. 
kusje z obecnymi profesorami, wypytując się w przyjacielskiej formie o warunki pracy, wyniki nauki oraz dopytujac o wrażenia z wycieczki nauczycielstwa polskiego w Butgarii. Po zwiedzeniu pracowni fizycznej, zajęć praktycznych i humanistycznej, goście żegnani owacyjnie przez młodzież, udali się do Pałacu Sztuk Pięknych ${ }^{18}$. Pobyt w Akademii trwał zaledwie 10 minut. W tym czasie swoje prace przedstawił ministrowi Radewowi prof. Konstanty Laszczka ${ }^{19}$.

Około godziny 14.00 minister Teodor Radew w towarzystwie swojego współpracownika Pirijowa złożył wizytę prezydentowi miasta M. Kaplickiemu. Po dłuższej rozmowie z włodarzem miasta goście zwiedzili ratusz. Kolejnym punktem pobytu bułgarskiego ministra w Krakowie była wizyta w Domu Związku Legionistów na Oleandrach. Ministra witał m.in. Mikołaj Kwaśniewski - wojewoda krakowski i równocześnie prezes okręgu Związku Legionistów, w towarzystwie wiceprezesów: L. Strojka i ppłk. Podgórskiego. Delegacja bułgarska w czasie zwiedzania zatrzymała się dłużej w Sali Kadrówki, gdzie znajdowała się makieta Oleandrów z 1914 r. oraz wykuty w marmurze historyczny rozkaz Józefa Piłsudskiego z sierpnia tegoż właśnie roku² ${ }^{20}$.

Drugi dzień pobytu ministra Teodora Radewa upłynął na zwiedzaniu Ojcowa i Wieliczki. W drodze do Ojcowa ministrowie Radew i Jędrzejewicz zatrzymali się najpierw w Bronowicach, później w Szycach, gdzie zwiedzili Uniwersytet Ludowy. Po krótkim pobycie w Ojcowie obaj ministrowie udali się do Wieliczki, gdzie zwiedzili kopalnię soli. „Ilustrowany Kuryer Codzienny” relacjonował ją w następujący sposób: Na nadszybiu „Danilowicza” "ustawily się w szeregach dzieci szkolne i młodzież, dalej hufce harcerzy oraz delegacje ze sztandarami. Gdy auta z gośćmi zajechaty na miejsce, orkiestra górnicza odegrata narodowy hymn bułgarski, poczem w imieniu miasta powitat gości burmistrz Jagielski w obecności wojewody dra Kwaśniewskiego, starosty dra Wnęka $i$ dyrektora salin Starnawskiego. Po przemówienia, dziewczynki w strojach krakowskich wręczyly gościom kwiaty. Po wpisaniu się do księgi pamiatkowej ministrowie wraz ze świta zjechali do kopalń, zatrzymując się dlużej w komorze Sienkiewicza, gdzie w czasie podwieczorku dziatwa szkolna zaprodukowata polskie tańce narodowe ${ }^{21}$. Obaj ministrowie otrzymali także pamiątkowe albumy ze zdjęciami z wielickiej kopalni. O godzinie 21.40 delegacja bułgarska odjechała z Krakowa w kierunku Dziedzic, kończąc tym samym swój pobyt w Polsce.

Ostatnim akcentem tej wizyty była depesza wystosowana przez ministra Teodora Radewa do ministra Wacława Jędrzejewicza, tuż przed opuszczeniem Polski. Jej treść brzmiała: Przed opuszczeniem terytorium Polski wyrażam Waszej Ekscelencji moje wielkie zadowolenie z powodu podpisania konwencji kulturalnej, której rezultatem będzie

\footnotetext{
18 Ibidem, s. 16.

19 Ibidem, s. 16.

${ }^{20}$ Min. Radew w ratuszu, „Ilustrowany Kuryer Codzienny” 1935, nr 103, s. 16.

${ }^{21}$ Min. Radew i min. Jędrzejewicz zwiedzili Ojców i Wieliczkę, „Ilustrowany Kuryer Codzienny” 1935, nr 104, s. 18.
} 
zacieśnienie węzłów przyjaźni istniejących między naszemi krajami. Jestem wdzięczny za gorace przyjęcie, jakie zechciat Pan mi zgotować22.

$\mathrm{Z}$ tej depeszy, jak przeanalizowanych relacji i komentarzy prasowych wynika, że wizyta ta miała duże znaczenie dla obu państw.

\section{Wizyta ministra oświaty Szwecji Artura Engberga}

Wizyta ministra Artura Engberga w Polsce trwała cztery dni. Odbyła się ona w dniach od 6 do 9 czerwca 1935 r. Cytowana już „Ilustrowana Republika” zamieściła następującej treści zapowiedź tej wizyty: Jutro [6 czerwca - przy. P.G.] popoludniu przybywa do Warszawy samolotem z oficjalna wizyta, na zaproszenie rzadu polskiego szwedzki minister oświaty $i$ wyznań p. Artur Engberg, któremu towarzyszyć będzie sekretarz stanu w szwedzkiem min. oświaty p. Knöes. W godzinach popoludniowych min. Engberg podejmowany będzie śniadaniem przez ministra spraw zagranicznych Becka. Po zwiedzeniu centralnego instytutu wychowania fizycznego min. Engberg weźmie udział w uroczystości inauguracji biblioteki szwedzkiej w Warszawie, poczem odjedzie pociagiem do Krakowa. Program pobytu min. Engberga w Krakowie obejmie - zwiedzenie szkół miejscowych, zapoznanie się z pamiatkami historycznemi Krakowa. Po zwiedzeniu Wieliczki min. Engberg odjedzie do Poznania, skąd $w$ dn. 9 bm., po zwiedzeniu miasta odleci samolotem do Berlina ${ }^{23}$.

Na łamach „Ilustrowanego Kuryera Codziennego” w dniu przybycia ministra Artura Engberga do Polski ukazał się krótki tekst stanowiący zapowiedź tego wydarzenia o charakterze kulturalno-oświatowym. Nie byłoby może w tym nic interesującego, gdyby nie fakt, że tekst ten, jako jedyny, został wzbogacony o krótki biogram szwedzkiego ministra oświaty. Autor tego anonsu prasowego tak napisał o Arturze Engberu: Min. Engberg urodzit się $w$ r. 1888. Po ukończeniu studiów na uniwersytecie $w$ Uppsali zająt się dziennikarstwem. W r. 1915 pracowat w redakcji dziennika „Arbetet” (Praca). W 1924 r. zostat naczelnym redaktorem dziennika „Socialdemokraten”. Od r. 1917 min. Engberg jest członkiem drugiej Izby parlamentu i bierze czynny udział $w$ życiu politycznym, będac powoływany na odpowiedzialne stanowiska w parlamencie i partii. Był członkiem komisji spraw zagranicznych Riksdagu i wiceprezesem komisji konstytucyjnej, jak również członkiem komisji mianowanych przez rząd w sprawach Ligi Narodów, jako członek delegacji szwedzkiej. Stanowisko ministra oświecenia publicznego i wyznań zajmuje od r. $1932^{24}$.

Samolot z ministrem wylądował na lotnisku Okęcie 6 czerwca 1935 r. Ministrowi oświaty towarzyszył jego zastępca Böjre Knöes. Przybycia szwedzkiego ministra oświaty na lotnisku oczekiwali między innymi: minister wyznań religijnych i oświecenia pus. 17.

${ }^{22}$ Podziękowanie min. Radewa za gościnę w Polsce, „Ilustrowany Kuryer Codzienny” 1935, nr 105,

${ }^{23}$ Ministrowie szwedzcy w Warszawie, „Ilustrowana Republika” 1935, nr 155, s. 2.

${ }^{24}$ Szwedzki minister oświaty przybędzie do Warszawy i Krakowa, „Ilustrowany Kuryer Codzienny” 1935, nr 155 , s. 15 . 
blicznego Wacław Jędrzejewicz, wiceminister tegoż resortu ks. Bronisław Żongołłowicz oraz prof. Konstanty Chyliński. Obecni byli także poseł szwedzki Boheman oraz konsul generalny Herslow. Po uroczystości powitania minister w towarzystwie osób oczekujących jego przybycia udał się do hotelu na odpoczynek ${ }^{25}$. Trzeba jednakże zauważyć, że odbyło się międzylądowanie w Poznaniu, gdzie ministra Engberga w imieniu MWRiOP powitał dr E. Zdrojewski oraz przedstawiciele władz miasta Poznania ${ }^{26}$.

Zaraz po powitaniu minister Engberg udał się do prywatnych apartamentów posła szwedzkiego Erika Bohemana, gdzie został podjęty obiadem. Obecni byli również: minister W. Jędrzejewicz, wiceminister ks. B. Żongołłowicz oraz profesorowie K. Chyliński, Pieńkowski, Warchałowski, Jeliński, Handelsman, Antoniewicz, Łempicki, Tatarkiewicz, prezes Towarzystwa Polsko-Szwedzkiego Pawlikiewicz i kilka innych osób z Uniwersytetu Warszawskiego i poselstwa szwedzkiego ${ }^{27}$.

Drugi dzień wizyty minister Artur Egnberg spędził w Warszawie. Dość szczegółowy przebieg tej wizyty opisany został na łamach „Dziennika Poznańskiego”. Podano nawet dokładnie godziny i minuty spotkań. Oto fragment: Szwedzki minister oświaty $i$ wyznań Artur Engberg oraz podsekretarz stanu B. Knoes złożyli wczoraj o 9-tej rano wizyte p. ministrowi oświaty Wacławowi Jędrzejewiczowi. O godz. $9.20 \mathrm{~min}$. A. Engberg, min. W. Jędrzejewicz i Knoes zwiedzili 7-klasowa publiczna szkołe powszechna nr $183 \mathrm{im}$. gen. Józefa Bema. Następnie goście szwedzcy zwiedzili państwowy instytut robót ręcznych. Ministrowie szwedzcy po złożeniu wieńca na grobie Nieznanego Żołnierza udali się do Belwederu, gdzie wpisali się do księgi żałobnej, oddajac hołd pamięci Wodza Narodu Marszatka Józefa Pitsudskiego. O godz. 12.40 ministrowie szwedzcy byli przyjęci przez p. prezesa rady ministrów W. Sławka, a o godz. 13-tej przez Pana Prezydenta RP, poczem zwiedzili Zamek królewski. O godz. $13.30 \mathrm{w}$ apartamentach p. ministra spraw zagranicznych odbyło się podpisanie protokotu ustalającego zasady wspótpracy kulturalnej pomiędzy Polska a Szwecją. Następnie p. minister Beck podejmowat gości szwedzkich śniadaniem $^{28}$.

Wspomniana wizyta w siedmioklasowej Szkole Powszechnej nr 183 im. generała Józefa Bema według opisu dziennikarzy „Kuriera Warszawskiego” wyglądała tak: Chór szkolny odśpiewat hymn szwedzki i polski. Goście obecni byli na lekcjach-poczem zwiedzili wystawe prac uczniów w szkole. Po wpisaniu się do księgi pamiątkowej gości szwedzkich, dzieci wręczyty im upominki z własnych prac. Szpalery dziecięce z choragiewkami szwedzkimi, wznoszac okrzyk w języku szwedzkim ,Leve sverige”, żegnaty go$\dot{s} c i^{29}$.

Po wizycie u ministra J. Becka szwedzka delegacja udała się do Centralnego Instytutu Wychowania Fizycznego. Ostatnim punktem wizyty tego dnia była uroczystość otwar-

${ }^{25}$ Szwedzki minister oświaty w Warszawie, „Gazeta Lwowska” 1935, nr 130, s. 1.

26 E. Z., Pobyt w Polsce szwedzkiego ministra oświaty, „Oświata i Wychowanie” 1935, nr 6, s. 449.

27 Minister Engberg $w$ Warszawie, „Kurier Warszawski” 1935, nr 155, s. 3.

${ }^{28}$ Konwencja o wspótpracy kulturalnej między Polska a Szwecja, „Dziennik Poznański” 1935, nr 133, s. 2.

${ }^{29}$ Min. Engberg $w$ Warszawie, „Kurier Warszawski” 1935, nr 156, s. 3. 
cia biblioteki szwedzkiej, która swoją siedzibę miała przy ul. Królewskiej 3. Rozpoczęła się ona o godzinie 17.20, a zagaił ją prof. Coleman - lektor języka szwedzkiego w Warszawie. W swoim wystąpieniu podkreślał coraz bardziej widoczne zainteresowanie w Polsce problemami życia społecznego i kulturalnego w Szwecji. Minister Engberg z kolei wyraził swoje zadowolenie i z faktu otwarcia biblioteki, i z faktu podpisania konwencji o wzajemnej współpracy kulturalnej, która przyczyni się z pewnością do rozwoju stosunków pomiędzy obu państwami ${ }^{30}$. Podkreślił także fakt coraz większego zainteresowania się Polski i życiem, i problemami kulturalnymi w Szwecji ${ }^{31}$. Minister Engberg mówił między innymi: Miło mi niezmiernie dokonać otwarcia tej biblioteki, która będzie jeszcze jednym wyrazem serdeczności uczuć między naszymi narodami. Podczas mego pobytu w Polsce mogłem z podziwem przekonać się, jak wielki naród polski potrafit $w$ krótkim czasie odbudować się nie tylko politycznie, ale i kulturalnie. Stosunki nasze byty zawsze przyjazne, to też zacieśnienie ich, dokonane podczas mojego obecnego pobytu $w$ Warszawie, któremu przypisuje wielkie znaczenie, będzie niezmiernie pożyteczne. Korzystam z tej sposobności, aby podziękować polskiemu ministrowi oświaty, za miłe przyjęcie jakiego doznałem i za uprzejme towarzyszenie mi w ciagu dzisiejszego dnia tak petnego interesujacych i niezapomnianych wrażen. Wierze gtęboko, że podpisany dziś protokót przyczyni się $w$ dużej mierze do zacieśnienia naszej wspótpracy, a otwarta świeżo biblioteka także będzie jedna z cegiełek gmachu przyjaźni polsko-szwedzkiej32.

Tego też dnia nastąpiło bowiem podpisanie umowy kulturalnej pomiędzy Polską a Szwecją. W myśl tej umowy oba państwa deklarowały nieustanną chęć rozwoju i wzmacniania wzajemnych stosunków na płaszczyznach: naukowej, literackiej i artystycznej. Umowa ta miała również ułatwić prowadzenie studiów historycznych nad dziejami stosunków polsko-szwedzkich. Zarówno w Polsce, jak i Szwecji miały powstać specjalne komisje, których celem byłoby organizowanie wymiany naukowej, ułatwiającej polskim naukowcom wygłaszanie wykładów w Szwecji i odwrotnie, szwedzkim przedstawicielom środowisk akademickich w Polsce ${ }^{33}$.

Na łamach „Oświaty i Wychowania”, organu prasowego Ministerstwa Wyznań Religijnych i Oświecenia Publicznego zawarto krótką relację z wizyty ministra Engberga w Polsce. Ujęto w niej dość szczegółowy opis poszczególnych punktów tych odwiedzin. Oto fragment tej relacji dotyczący wymiany odznaczeń pomiędzy delegacją szwedzką a przedstawicielami polskiego ministerstwa oświaty: Dnia 7 czerwca po złożeniu wizyty p. Ministrowi W. Jędrzejewiczowi, podczas której p. wiceminister Knös otrzymat z rąk p. Ministra W.R.i.O.P. odznaki Komandorji z gwiazda, Orderem Odrodzenia Polski, a p. Minister Engberg udekorowat p. Ministra Jędrzejewicza wielka wstęga Orderu Gwiazdy Polarnej i radce dr. Zdrojewskiego komandorja orderu Wazy, goście szwedzcy wraz z postem Szwecji Bohemanem w towarzystwie Ministra Jędrzejewicza, dyrektora

\footnotetext{
${ }^{30}$ Konwencja o wspólpracy, op. cit., s. 2.

31 Min. Engberg w Warszawie, „Kurier Warszawski” 1935, nr 156, s. 3.

32 Co mówi min. Engberg o swych wrażeniach w Warszawie, „Ilustrowany Kuryer Codzienny” 1935, nr 158 , s. 14.

${ }^{33}$ E. Z., Pobyt $w$ Polsce, op. cit., s. 449.
} 
Mendysa, kuratora Pytlakowskiego i radcy Zdrojewskiego zwiedzili Państwowy Instytut Robót Ręcznych przy ul. Górczewskiej 8 i szkołe powszechna przy ul. Bema $76^{34}$.

Jeszcze wieczorem w towarzystwie ministra Jędrzejewicza minister Engberg wyjechał do Krakowa. W dawnej stolicy Polski pojawił się niespełna pół godziny przed północą.

Przed wyjazdem delegacji szwedzkiej do Krakowa jednemu z dziennikarzy współpracujących z „Ilustrowanym Kuryerem Codziennym” udało się przeprowadzić krótkie wywiady zarówno z ministrem Engbergiem, jak i ministrem Jędrzejewiczem. Swoje wrażenia szwedzki minister wyraził tak: Jestem zachwycony moim pobytem $w$ Warszawie. Obejrzałem szkołę robót ręcznych, centralny Instytut Wychowania Fizycznego, złożyłem wizytę P. Prezydentowi Rzeczypospolitej, który zechcial łaskawie mnie przyjąć, jak również p. prezesowi rady ministrów. Podejmowali mnie jak najserdeczniej ministrowie spraw zagranicznych $i$ oświecenia publicznego. $Z$ wielka przyjemnościa stwierdziłem bardzo wysoki poziom instytutu robót ręcznych oraz szkoły powszechnej im. Bema, która zwiedziłem, a wzruszajaca niespodzianka dla mnie było, że dzieci powitały mnie okrzykiem: „Niech żyje Szwecja” po szwedzku, a następnie odśpiewaty również po szwedzku nasz hymn narodowy tak doskonale $i$ z tak świetnym akcentem, że po prostu uszom swym nie wierzyłem. Lekcja była poświęcona również częściowo Szwecji, nauczyciel przełożyt mi ja na szwedzki. Zewsząd spotykało mnie tyle sympatii zarówno ze strony osób urzędowych, jak prywatnych, że jestem tem wszystkiem wręcz rozczulony. Z wielkim zadowoleniem stwierdzam, że udało się nam podpisać protokół o rozszerzeniu stosunków kulturalnych między naszymi narodami, dajacy rozległe możliwości w szerokiej współpracy $w$ ramach tym protokółem utrwalonych. Jestem przekonany, że wszystko będzie niezmiernie pożyteczne dla przyszłego ukształtowania się naszych stosunków kulturalnych. Chciatbym jeszcze raz wspomnieć, że ogromne wrażenie wywart na mnie centralny instytut wychowania fizycznego na Bielanach, który uważam za wzór podobnego rodzaju instytucji. Żałowałem niezmiernie, że odwiedziny moje wypadty $w$ okresie ciężiej żałoby narodowej, która zjednoczyła cała Polskę. Nie trudno mi było wyczuć, jak dalece zidentyfikowane byty losy Polski ze zgasła osoba Twórcy jej odrodzenia i jak głęboko odczuwała te śmierć ludność polska bez różnicy warstw ${ }^{35}$.

Wywiadu udzielił także minister W. Jędrzejewicz, który pojawił się chwilę później na dworcu. Wyraził on m.in. zadowolenie z faktu, że wizyta doszła do skutku, a także z tego, że udało się podpisać umowę kulturalną polsko-szwedzką. Uznał wizytę szwedzkiego ministra jako kolejny element zacieśniania przyjaźni pomiędzy obu państwami. Zapowiedział także swoją wizytę w Sztokholmie. Jędrzejewicz podkreślił również, że zamierza ministrowi Engbergowi - w ostatnich dwóch dniach wizyty w Krakowie i Poznaniu pokazać interesujące obiekty, aby mógł wywieźć jak najlepsze wrażenia „czysto-szkolne i kulturalne" 36 .

\footnotetext{
34 Ibidem, s. 449.

${ }_{35}$ Co mówi min. Engberg o swych wrażeniach w Warszawie, „Ilustrowany Kuryer Codzienny” 1935 , nr 158 , s. 14 .

36 Ibidem, s. 14.
} 
8 czerwca 1935 r. minister Engberg w towarzystwie W. Jędrzejewicza wizytował w Krakowie. W towarzystwie m.in. kuratora Godeckiego zwiedził Kościół Mariacki, Muzeum Narodowe i Bibliotekę Jagiellońską. W dalszej części dnia delegacja szwedzka odwiedziła Szkołę Przemysłową i gimnazjum żeńskie na Oleandrach.

Wizyty w obu placówkach oświatowych zrelacjonował „Ilustrowany Kuryer Codzienny”. I tak z relacji tej można się dowiedzieć, że wizyta w Państwowej Szkole Przemysłowej rozpoczęła się o godzinie 9.50. Szwedzkiego ministra oraz pozostałych gości powitał dyrektor tej placówki - inż. Kostecki. Po ceremonii powitania nastąpiło zwiedzanie warsztatów szkolnych. Na zakończenie wizyty dyrektor wręczył A. Engbergowi specjalne teczki ozdobione motywami krakowskim, w których znalazły się prace uczniów. Następnym punktem programu było zwiedzanie gimnazjum żeńskiego: Następnie goście szwedzcy udali się do gimnazjum w Oleandrach im. Królowej Wandy, gdzie powitała ich dyrektorka p. Józefa Bergruen. Ministrowie wraz z towarzyszacymi panami przeszli szpalerem młodzieży ustawionym na schodach, z której część była w strojach krakowskich, następnie przeszli goście do auli zakładowej. U wejścia do tejże chór gimnazjalny odśpiewat hymn „Jeszcze Polska nie zginęła”, poczem uczennica Bandrowska przemówiła po polsku, składając na ręce szwedzkich gości pozdrowienia dla młodzieży szwedzkiej. Uczennice wręczyly wiąanki kwiatów ministrom i towarzyszacym panom, chór zaś odśpiewat następnie hymn szwedzki w języku szwedzkim. Przy wyjściu p. minister szwedzki złożył serdeczne podziękowania za przywitanie, podnoszac wartość szkół żeńskich zaznaczając, że szkoty żeńskie ksztatca wszakże przyszłe matki, a te przyszłe pokolenia. Pobyt gości szwedzkich w gimnazjum żeńskim trwał 45 minut ${ }^{37}$.

Po zwiedzeniu zakładów oświatowych przedstawiciel szwedzkiego rządu złożył wizytę prezydentowi Krakowa Kaplickiemu. W Grand Hotelu na cześć gościa szwedzkiego minister Jędrzejewicz wydał śniadanie. Następnie minister Engberg złożył wieniec przy trumnie Marszałka Piłsudskiego na Wawelu. Wziął też udział w usypywaniu kopca Marszałka Piłsudskiego w Sowińcu. W godzinach popołudniowych przedstawiciele szwedzkich i polskich ministerstw oświaty udali się do Wieliczki, gdzie zwiedzili ,saliny wielkickie". O godzinie 22.00 szwedzki minister światy w towarzystwie swoich współpracowników udał się w podróż do Poznania ${ }^{38}$.

Ostatni dzień swojego pobytu w Polsce minister Engberg spędził w Poznaniu. Czy dla poznaniaków była to jakaś znacząca wizyta, trudno powiedzieć. Jeśli odnieść się do anonsów prasowych, to „Kurier Poznański” informował o tym na stronie siódmej wydania głównego z dnia 12 czerwca 1935 r., a więc trzy dni po tym, jak minister opuścił Poznań. Notatka była lakoniczna: W pierwsze święto rano przybyli z Krakowa do Poznania na krótki pobyt szwedzki minister oświaty p. James Artur Engberg i wicemin. oświaty p. Knöes. W godzinach porannych goście zwiedzili wystawę Szkoły Zdobniczej. Po zwiedzeniu Muzeum ratusza i gmachu anatomii wyjechali przez Berlin do Sztokholmu ${ }^{39}$.

\footnotetext{
37 Dzień szwedzkiego ministra oświaty w Krakowie, „Ilustrowany Kuryer Codzienny” 1935, nr 159, s. 7.

38 Szwedzki minister oświaty w Krakowie, „Czas” 1935, nr 157, s. 2.

39 Szwedzki Min. Oświaty w Poznaniu, „Kurier Poznański” 1935, nr 265, s. 7.
} 
W tekście umieszczonym w lewym dolnym narożniku szpalty opublikowano także zdjęcie ministra.

Nieco bardziej szczegółowo odniósł się do tego „Dziennik Poranny”, informując, że delegacja szwedzka pojawiła się na dworcu w Poznaniu o godzinie dziewiątej rano, w towarzystwie ministra W. Jędrzejewicza. Po powitaniu rozpoczęło się zwiedzanie miasta, a przede wszystkim szkół i innych placówek oświatowych. Minister Engberg gościł $\mathrm{w}$ pracowni robót ręcznych w gimnazjum państwowym im. Bergera, na wystawie obrazów w państwowej szkole sztuk zdobniczych. Zwiedził także szkolny ogród botaniczny i był na placu budowy państwowej szkoły ogrodniczej. Zapowiadano również, że Szwedzi zwiedzą zamek w Kórniku ${ }^{40}$. De facto jednakże do Kórnika udali się tylko przedstawiciele polskiego ministerstwa finansów, z ministrem Jędrzejewiczem na czele ${ }^{41}$.

Czytelnicy „Dziennika Poznańskiego” mieli okazję zapoznać się z przebiegiem wizyty za pomocą przekazu ikonograficznego. Dość zmyślnego zresztą. W numerze 132 $\mathrm{z}$ dnia 8 czerwca na pierwszej stronie opublikowano zdjęcie $\mathrm{z}$ następującym podpisem: $W$ dniu wczorajszym Poznań gościł $w$ Lawicy przez 20 min. bawiacych $w$ przelocie do Warszawy szwedzkiego ministra oświaty p. Jonesa Artura Engberga (w górnem kole) $i$ wiceministra oświaty p. Bödie Olafa Knoes'a. Ministrów witat m.in. honorowy konsul szwedzki w Poznaniu p. dyr. Legis ${ }^{42}$.

Podobnie skomentowano ostatni dzień pobytu ministra w Poznaniu. Opublikowano zdjęcie wyobrażające odlatujący samolot z ministrem Engbergiem, wzbogacone małymi zdjęciami umieszczonymi w narożnikach głównej fotografii. Na jednym powitanie ministra na dworcu kolejowym w Poznaniu, na drugim delegacja szwedzka tuż przed odlotem $^{43}$.

Trzeba zwrócić jeszcze uwagę na jeden fakt. Otóż na kilka dni przed przyjazdem ministra Engberga do Poznania w mieście tym z inicjatywy Stowarzyszenia Polsko-Szwedzkiego działającego w stolicy Wielkopolski odbyło się uroczyste zebranie, którego celem było uczczenie święta narodowego Szwecji. Na wstępie prezes Stow. p. A. Mueller wypowiedział pod adresem narodu szwedzkiego oraz jego króla życzenia dalszego pomyślnego rozwoju. Mówca wskazał następnie na zacieśniające się coraz silniej stosunki polsko-szwedzkie, petne obopólnej przyjaźni i sympatii oraz wspomniał o pożytecznej działalności Stowarzyszenia Polsko-Szwedzkiego na polu zbliżenia między obydwoma narodami ${ }^{44}$. Zebrani wysłuchali jeszcze dwóch referatów dotyczących pięćsetlecia parlamentu szwedzkiego oraz budownictwa podmiejskiego w Szwecji. Zebranie zgromadziło wiele osób. I choć nie wspominano o zbliżającej się wizycie szwedzkiego ministra oświaty - przynajmniej prasa tego nie odnotowała - to trzeba stwierdzić, że takie spotkanie

\footnotetext{
${ }^{40}$ Ministrowie szwedzcy $w$ towarzystwie min. Jędrzejewicza przybywaja dziś do Poznania, „Dziennik Poranny" 1935 , nr 84, s. 4.

${ }^{41}$ Ministrowie szwedzcy zwiedzili Poznań, „Dziennik Poranny” 1935, nr 85, s. 4.

${ }^{42}$ Ministrowie szwedzcy na lotnisku $w$ Eawicy, „Dziennik Poznański” 1935, nr 132, s. 1.

43 Z pobytu szwedzkich ministrów w Poznaniu, „Dziennik Poznański” 1935, nr 134, s. 1.

${ }^{4}$ Uroczyste zebranie z okazji święta narodowego Szwecji, „Dziennik Poranny” 1935, nr 82, s. 4.
} 
stanowiło doskonałe wprowadzenie do tej wizyty i do jej obserwacji nie tylko przez społeczeństwo Poznania.

Opuszczając Polskę, minister wyraził zadowolenie z przebiegu wizyty. W rozmowie z dziennikarzem podkreślał, że niezwykle wzruszony był serdecznym przyjęciem. Jego zadowolenie wzbudzały flagi szwedzkie wywieszane w miastach i miejscach, w których przebywał. Duże wrażanie wywarły na nim także polskie szkoły. Wyraził również nadzieję na rewizytę ministra W. Jędrzejewicza jeszcze we wrześniu 1935 r. ${ }^{45}$

\section{Wizyta ministra oświaty Węgier Bálinta Hómana}

Ostatnim ministrem oświaty, który odwiedził Polskę w 1935 r., był przedstawiciel rządu węgierskiego - Bálint Hóman. Nie był to pierwszy węgierski minister tego resortu, który wizytował Rzeczpospolitą. Cztery lata wcześniej obecny był minister Kuno Klebersberg. Na czele polskiego Ministerstwa Wyznań Religijnych i Oświecenia Publicznego stał wówczas Sławomir Czerwiński.

Wizyta węgierskiego ministra miała nieco odmienny cel od dwóch wcześniej opisanych. Deklarację o współpracy podpisano bowiem już w roku 1934, a Bálint Hóman przybył do Polski, aby podsumować pierwszy rok jej funkcjonowania. Wizyta ta różniła się także pod kątem programu. Minister poza Warszawą i Krakowem odwiedził też Wilno. Rozpoczął swój pobyt w Polsce 3 listopada 1935 r. (w Warszawie), a zakończył 9 listopada (w Krakowie).

W przeddzień tej wizyty ukazał się na łamach „Ilustrowanego Kuriera Codziennego" obszerny artykuł napisany przez samego węgierskiego ministra - zatytułowany Polska $i$ Wegry dwoma bastionami zachodniej cywilizacji. Tekst ten stanowił dość szczegółową i dogłębną analizę stosunków polsko-węgierskich na przestrzeni wieków. Rozpoczynał się od legendarnego pojednania obu narodów w czasach św. Stefana: według legendy ten naród, który zerwałby przyjaźń, narażał się na klątwę kościelną. Kończył się zaś opisem sytuacji współczesnej, w której znalazły się oba państwa ${ }^{46}$.

Natomiast w pierwszym dniu wizyty ministra Hómana w Polsce na łamach krakowskiego „Czasu” ukazał się artykuł będący de facto prezentacją sylwetki węgierskiego ministra oświaty. Jego autorem był Jan Dąbrowski. Określił on Hómana jako najznamienitszego węgierskiego uczonego. Węgierski minister oświaty z wykształcenia był historykiem i zasłynął przede wszystkim ze znakomitych studiów nad średniowiecznymi dziejami, szczególnie w kontekście gospodarczym, a także nad źródłami do dziejów Węgier. Dąbrowski za najlepsze dzieła Hómana uznał te dotyczące praktyki finansowej Karola Andegaweńskiego i finansów Węgier. Za najbardziej doniosłą publikację uznał zaś $\mathrm{Hi}$ storię Węgier napisaną wspólnie z profesorem Szekfü. Bálint Hóman przed objęciem teki ministra był wykładowcą w katedrze historii węgierskiej na uniwersytecie budapesztań-

\footnotetext{
${ }^{45}$ Min. Engberg powrócit do Sztokholmu, „Czas” 1935, nr 159, s. 2.

${ }^{46}$ Polska $i$ Wegry dwoma bastionami zachodniej cywilizacji, „Ilustrowany Kurier Codzienny” 1935, nr 306, s. 3-4.
} 
skim i jednocześnie dyrektorem Węgierskiego Muzeum Narodowego. Autor opisał działalność Bálinta Hómana na stanowisku ministra oświaty: Jako minister oświaty zaznaczyt się prof. Hóman zarówno dbałością o należyty poziom szkolnictwa, zwłaszcza średniego, jak również o potrzeby nauki i szkół wyższych i zdołał rozwiązać pomyślnie trudne problemy wywołane koniecznościa oszczędności w czasach kryzysu, zapewniając środki potrzebne dla rozwoju tak nauki, jak wszechnic, których dorobek stanowi dziś stuszna chlube Wegier. Zainteresowania naukowe prof. Hómana zapoznały go też z niejednem zagadnieniem przeszłości Polski, dla stosunków naukowych z Polska okazywał zawsze wielkie zrozumienie $i$ nie szczędzit im poparcia, a jego przybycie do Polski jest nowym tego $i$ tak dla nas mitym i pożadanym dowodem ${ }^{47}$.

Pierwszym dniem oficjalnej wizyty był 4 listopada 1935 r. Można go uznać za intensywny, aczkolwiek dość przyjemny dzień. Na łamach „Oświaty i Wychowania” program tego dnia streszczono następująco: Pierwszy dzień pobytu, 4 listopada przybyli goście rozpoczęli od złożenia wizyty p. Kierownikowi Ministerstwa W.R.iO.P., podczas której Minister Homan udekorowat p. Ministra Chylińskiego Wielka Wstęga Węgierskiego Orderu Zastugi Narodowej, a Minister Chyliński Ministra Homana i sekretarza stanu Szillyego odznakami Wielkiej Wstęi Orderu Odrodzenia Polski, naczelnika Villaniego Złotym Krzyżem Zastugi i radce Terbocza Komandorja Orderu Odrodzenia Polski. Następnie przybyli goście wraz z pp. Ministrem Chylińskim, dyrektorem Mendysem, kuratorem Pytlakowskim, naczelnikiem Maciszewskim i radca Zdrojewskim udali się na zwiedzanie gimnazjum im. Batorego. Po przyjęciu rewizyty p. Ministra Chylińskiego, Minister Homan złoży wieniec na Grobie Nieznanego Żotnierza, poczem udat się do p. Wiceministra Spraw Zagranicznych Szembeka, który wydat na jego cześć śniadanie. Po południu odbyła się inauguracja Instytutu Wegierskiego, a wieczorem obiad i raut wydany przez p. Ministra Chylińskiego ${ }^{48}$.

Już pierwszego dnia wizyty Bálint Hóman został uhonorowany tytułem doctora honoris causa z filozofii Uniwersytetu Warszawskiego im. Józefa Piłsudskiego. Uroczystość zgromadziła przedstawicieli polskiego Ministerstwa Wyznań Religijnych i Oświecenia publicznego, poselstwa węgierskiego i co oczywista, świata naukowego. Postać ministra i jego zasługi na polu nauki scharakteryzował $\mathrm{w}$ swoim przemówieniu prof. Handelsman, podkreślając także wkład Hómana w rozwój stosunków polsko-węgierskich na płaszczyźnie naukowej i kulturalnej. Mówca oświadczyt, że w uznaniu zastug min. Homana dla rozwoju nauki węierskiej $w$ dziedzinie badań nad stosunkami polsko-węgierskimi uniwersytet J.P. postanowit nadać mu doktorat filozofii honoris causa ${ }^{49}$. Następnie prof. Antoniewicz odczytał treść dyplomu i wręczył go Bálintowi Hómanowi. Węgierski minister oświaty podziękował w języku łacińskim za zaszczytne wyróżnienie. Powiedział również, że ta uroczystość będzie ogniwem $w$ złotym łańcuchu po wsze czasy łączącym kulturę humanitaryzmu Polaków i Węgrów, a także wzajemna wielowiekowa

\footnotetext{
47 J. Dąbrowski, Prof. dr. Hóman węgierski minister oświaty, „Czas” 1935, nr 303, s. 6.

48 E. Z., Pobyt w Polsce węgierskiego ministra oświaty, „Oświata i Wychowanie” 1935, nr 8-9, s. 685-686.

49 Węgierski minister oświaty w Warszawie, „Kurier Warszawski” 1935, nr 305, s. 3.
} 
przyjaźń obu narodów, tylu nieszczęściami dotkniętych ${ }^{50}$. Po uroczystości rektor Pieńkowski podjął węgierskiego ministra śniadaniem w Resursie Kupieckiej.

Ważnym punktem wizyty węgierskiego ministra oświaty było otwarcie Instytutu Węgierskiego - co było jednym z wielu elementów realizacji podpisanej rok wcześniej umowy kulturalnej pomiędzy obu państwami. Uroczystość, która odbyła się w sali kolumnowej Pałacu Staszica (siedziba Instytutu), zgromadziła dużą liczbę przedstawicieli środowisk naukowych, polskich władz oświatowych i oczywiście członków węgierskiej delegacji z ministrem Bálintem Hómanem na czele. Pierwszy wystąpił prof. Sierpiński, który przemówił w języku francuskim, witając węgierskiego gościa i wyrażając radość z faktu otwarcia Instytutu. Prof. Diveky poprosił ministra Hómana o dokonanie aktu otwarcia Instytutu Węgierskiego. Przy tej okazji węgierki minister oświaty wygłosił przemówienie po łacinie, w którym mówił o nierozerwalnych więzach łączących Polskę i Węgry. Po uroczystości otwarcia Instytutu głos zabrał jego szef prof. Diveky, który $\mathrm{w}$ referacie wygłoszonym w języku polskim dał wykład z dziejów stosunków polsko-węgierskich na przestrzeni kilku wieków. Mówił m.in.: Uniwersytet Jagielloński byt Mekka dla młodzieży węgierskiej. Z końcem XV wieku 17 proc. studentów tej Wszechnicy to Węrzy, którzy mieli w Krakowie własna bursę i kaplicę. Pierwsze ksiązki w języku węgierskim były wydrukowane w Krakowie, a m.in. pierwsza gramatyka węierska. Szkota Wita Stwosza rozpowszechniła swe wpływy na Wegry. Niezliczone sa podobieństwa $w$ dziedzinie organizacji państwowej $i$ ustawodawstwie. Niestety przyjazne zbliżenie nie może być należycie pogłębiane, a to z powodu braku bardziej gruntownych wiadomości w Polsce o Wegrzech. Dotychczas nie mamy dobrych podręczników nauki języka polskiego dla Węgrów i węgierskiego dla Polaków. Nie ma też dotychczas stownika polsko-węgierskiego. Przekłady dzieł literackich często dokonywane sa z języka niemieckiego. Stąd też ustawiczne usterki i braki. Celem Instytutu będzie umożliwienie Polakom interesujacym się historia i kultura Węgier, zdobywania odpowiednich źródet. Instytut posiada biblioteke, której wzbogacanie będzie troska czynników węgierskich. W Instytucie znajda badacze polscy pomoc $w$ studiach nad różnemi dziedzinami wiedzy $y^{51}$.

Minister Hóman, mówiąc o wizycie w Polsce, wskazał na kilka ważnych jej aspektów. W wywiadzie udzielonym dziennikarzom Polskiej Agencji Telegraficznej powiedział: Narody polski i węgierski łączyły poprzednio tylko węzly polityczne. Nieco później zawarty byt uktad gospodarczy, a niedawno uzupetnito poprzednie uktady zawarcie umowy kulturalnej, która szefowie rząów obu państw w dniu 21 października 1934 r. zatwierdzili i która następnie ratyfikowały oba parlamenty. Celem mojej podróży do stolicy Polski jest wprowadzenie $w$ życie tego układu ramowego lub lepiej mówiąc przygotowanie praktycznych prac. Drugim celem mojego tutaj pobytu jest zapoznanie się z wszelkiego rodzaju urzadzeniami, pozostajacemi na ustugach polskiej kultury, oświaty i nowoczesnej polskiej polityki kulturalnej. Poza tem, moge to powiedzieć otwarcie, przybytem do Polski z tem większa radościa, że dato mi to sposobność do uzupetniania na miejscu całej wiedzy, nabytej podczas mych studiów nad całokształtem stosunków polsko-węgier-

\footnotetext{
50 Ibidem, s. 3.

${ }^{51}$ Uroczyste otwarcie Instytutu Węgierskiego, ,Ilustrowany Kurier Codzienny” 1935, nr 308, s. 3.
} 
skich. Pod każdym z tych trzech względów podróż moja muszę uważać za udaną. Wszystko, co tu widziałem, muszę powitać z jak największym uznaniem. Muszę té̇ podziękować za miłe przyjęcie $i$ serdeczna gościnność. Myślę teraz ze specjalna wdzięcznościa o panu prezesie rady ministrów Kościałkowskim, o panu ministrze oświaty Chylińskim i o wiceministrze ks. Żongołłowiczu, którzy to panowie we wszystkich moich poczynaniach udzielali mi swego poparcia. Jestem głęboko przekonany, że to przyjazne nawiąanie kontaktu będzie nowym krokiem ku pogłębieniu i zacieśnieniu naszej przyjaźni. Podczas prowadzonych przeze mnie rozmów i narad oraz przy zwiedzaniu warszawskich instytucji kulturalnych, przekonatem się, że polska polityka kulturalna z cała świadomościa swych celów zajmuje się aktualnem obecnie w całej Europie zagadnieniem polityki szkolnej. $W$ nowej organizacji szkót, tzn. kierowników tej organizacji dostrzegtem te same zasadnicze idee i poglądy, któremi kierowano się przy reformie szkolnictwa na Węgrzech. Dażenia i cele sa tutaj te same, co u nas. Dostrzegtem również troskę o to, aby kultura uczacej się $w$ rozmaitych szkołach $i$ do rozmaitych klas społecznych należacej młodzieży oparta była na wspólnej podstawie oraz o to, aby młodzież, przygotowujaca się do rozmaitych zawodów, otrzymała szeroko ujęte wykształcenie ogólne. Jako historyk, rzecz oczywista, odniostem najgłębsze wrażenie podczas rozmowy z historyczna osobistościa państwa polskiego - Prezydentem Ignacym Mościckim. Jako człowiek prywatny czutem się głęboko wzruszony podczas nadawania mi doktoratu honorowego na uniwersytecie Józefa Pitsudskiego. Wreszcie, jako minister oświaty bytem zachwycony znakomitem przygotowaniem uczniów oraz nowoczesnymi metodami nauczania w gimnazjum Stefana Batorego, dalej-odpowiadajacym duchowi naszych czasów systemem nauczania w szkole początkowej im. Bema i w końcu - wspaniała organizacja centralnego Instytutu wychowania fizycznego, który wspominać będę zawsze z podziwem. Cieszę się, że dzięki uprzejmości mego polskiego kolegi miałem możność zapoznać się ze wszystkiem $i$ że $w$ ten sposób zdobyte tutaj doświadczenia będę mógł wykorzystać w mej dalszej działalności na stanowisku ministra oświaty ${ }^{52}$.

Z powyższego wynika, że minister Hóman ogólnie zadowolony był z pobytu w Polsce, ze spotkań w placówkach oświatowych. Wypowiedź wydaje się jak najbardziej szczera i nie należy jej raczej traktować jako kurtuazyjnej czy poprawnej dyplomatycznie. Ciekawostką jest to, że węgierski minister oświaty odwiedził placówki, którym patronowały osoby związane z dziejami Węgier - Stefan Batory i Józef Bem.

Prasa, a ściślej mówiąc krakowski „Czas”, odnotowała dość szczegółowo jeszcze jeden fakt z bytności ministra Hómana w Warszawie. Otóż na cześć węgierskiego ministra oświaty poseł węgierski rezydujący w Polsce wydał raut w salonach pałacu Rzyszczewskich (siedziba poselstwa węgierskiego w Warszawie). Atmosferę panującą na tym przyjęciu scharakteryzowano następująco: Jak zwykle u naszych przyjaciół węgierskich nastrój panowat przemity i każdy czut się jak u siebie zwłaszcza, że poset de Horyi z iście węgierska serdecznościa i gościnnościa , robit honory”. Doskonały węgrzyn, podawany obficie $i$ w licznych odmianach, spotęgowat jeszcze ten mity nastrój ${ }^{53}$. Autor tej notatki,

52 Min. Homan o swoim pobycie w Polsce, ,Kurier Warszawski” 1935, nr 306, s. 3.

${ }^{53}$ Raut w poselstwie węgierskim, „Czas” 1935, nr 307, s. 8. 
zapewne uczestnik tegoż rautu - zaproszono bowiem sporą grupę dziennikarzy - opisał również postawę ministra Hómana w czasie tego rautu: Wśród przepetniajacych piękne sale i salony gości, zauważyliśmy przede wszystkiem postać węgierskiego ministra wyznań i oświaty, czarującego wszystkich niezwyktym urokiem osobistym, ujmując prostota i niefrasobliwym humorem. Rzadko kiedy tak wielka erudycja łączy się z takim ,koleżeńskim” usposobieniem ${ }^{54}$. W dalszej części wymienieni zostali jak można przypuszczać najznamienitsi goście bawiący na przyjęciu w węgierskim poselstwie - ministrowie, dyplomaci, przedstawiciele duchowieństwa, wykładowcy akademiccy, literaci, dziennikarze i członkowie towarzystwa polsko-węgierskiego.

Spośród trzech ministrów oświaty odwiedzających Polskę w 1935 r. tylko Bálint Hóman odwiedził Wilno. Wizyta ta miała miejsce 7 listopada 1935 r. Rozpoczęła się ona od złożenia hołdu sercu Marszałka Piłsudskiego w kościele św. Teresy. Hómanowi towarzyszyło w tym kilka osób, z ministrem Chylińskim na czele. Później w towarzystwie prof. Moralewskiego i ks. Puciaty zwiedzili oni kaplicę w Ostrej Bramie i kilka innych kościołów, w tym św. Anny i św. Piotra i Pawła na Antokolu. Kolejnym elementem programu była wizyta w bibliotece uniwersyteckiej i w samym uniwersytecie Stefana Batorego. „Wspią" się także węgierski minister na górę Bekieszową, gdzie według legendy miał być pochowany Kasper Bekiesz, wódz wojsk węgierskich z czasów Stefana Batorego. Zwiedził również kilka zakładów szkolnych, w tym szkołę powszechną na Antokolu i gimnazjum im. Elizy Orzeszkowej. O godzinie 14.00 odbyło się spotkanie z byłym rektorem Zdziechowskim i innymi profesorami wileńskiego uniwersytetu. Kwadrans przed 19 w sali kolumnowej Uniwersytetu Stefana Batorego odbyło się uroczyste powitanie ministrów oświaty Węgier i Polski. Orkiestra 3 pułku piechoty i chór akademicki wspólnie odegrały i odśpiewały hymny obu państw, zaś przemówienia wygłosili rektor uniwersytetu Witold Staniewicz i prezes Towarzystwa Przyjaciół Węgier Marian Zdziechowski. Po tej uroczystości został wydany na cześć gości obiad, a o 20.50 delegacje obu ministerstw wyruszyły w podróż powrotną do Warszawy ${ }^{55}$.

Kolejnym miastem na trasie podróży ministra Hómana po Polsce był, podobnie jak w dwóch wcześniej opisanych przypadkach, Kraków. W mieście tym przedstawiciel węgierskiego rządu pojawił się w piątek po południu - 8 listopada. Powitanie na dworcu krakowskim było bardzo uroczyste i zgromadziło wielu znakomitych mieszkańców królewskiego grodu. W salonie recepcyjnym ustawity się szpalerem poczty sztandarowe młodzieży męskiej i żeńskiej szkół średnich. Na dworcu powitali ministra Hómana przedstawiciele miejscowych władz z p.o. wojewody drem Małaszyńskim, wiceprezydentem Klimeckim i prorektorem prof. drem Krzyżanowskim na czele oraz konsul węg. Dyduch. Przybyli również członkowie towarzystwa polsko-węgierskiego z prezesem ks. biskupem drem Godlewskim, prof. drem Sroczyńskim oraz członkowie tutejszej kolonii węgierskiej i akademickiego koła przyjaciót Węier ${ }^{56}$.

\footnotetext{
54 Ibidem, s. 8.

55 Wegierski minister oświaty w Polsce, „Kurier Warszawski” 1935, nr 307, s. 3.

${ }^{56}$ Wegierski minister oświatowy w Krakowie, „Ilustrowany Kurier Codzienny” 1935, nr 312, s. 18.
} 
Pierwszym punktem wizyty w krakowskim grodzie było śniadanie wydane przez konsula węgierskiego Dyducha. O 16.30 Bálint Hóman pojawił się na Wawelu, gdzie złożył wieniec przy trumnie Marszałka Piłsudskiego i króla węgierskiego Stefana Batorego. Zwiedził także zamek. Udał się też na spotkanie z kardynałem Sapiehą. O godzinie 6.00 wieczorem na cześć ministra Hómana z inicjatywy Towarzystwa Polsko-Węgierskiego, Węgrów mieszkających w Krakowie oraz Akademickiego Koła Przyjaciół Węgier zorganizowano spotkanie przy herbatce. Przy tej okazji przemówienie powitalne wygłosił ks. biskup Godlewski - prezes Towarzystwa Polsko-Węgierskiego. Pod koniec spotkania głos zabrał także dr Harajda, który w imieniu Akademickiego Koła Przyjaciół Węgier podkreślił, że na Uniwersytecie Jagiellońskim współpraca kulturalna pomiędzy obu państwami istnieje nieprzerwanie od początków uczelni, a obecni studenci pracują nieustannie nie tylko nad jej podtrzymaniem, ale także rozwojem i zbliżeniem obu narodów. Prezes Akademickiego Koła - Susułowska wręczyła ministrowi Hómanowi ozdobne wydanie Kazań Świętokrzyskich. Bálint Hóman, dziękując za ten prezent, oświadczył, że cieszy go fakt, że nad utrzymaniem i pogłębieniem stosunków polsko-węgierskich pracuje nie tylko starsze pokolenie, ale także i młodzież. Pierwszy dzień wizyty w Krakowie zakończył się obiadem wydanym na cześć ministra Bálinta Hómana przez rektora Uniwersytetu Jagiellońskiego - prof. dra Maziarskiego ${ }^{57}$.

Ostatni dzień wizyty w Krakowie, a zarazem w Polsce rozpoczął się dość wcześnie rano i był bardzo intensywny. Węgierskiemu ministrowi w tym dniu towarzyszył przybyły specjalnie z Warszawy wiceminister oświaty - ks. Bronisław Żongołłowicz. Delegacja złożona z obu ministerstw zwiedziła gmach uniwersytetu, Bibliotekę Jagiellońską oraz żeńskie gimnazjum państwowe im. Królowej Wandy. Minister Bálint Hóman spotkał się także z sekretarzem generalnym Polskiej Akademii Umiejętności - prof. Kutrzebą. Jeszcze przed południem udał się na Sowiniec, gdzie wziął udział w usypywaniu kopca ku czci Marszałka Józefa Piłsudskiego. Po powrocie z Sowińca węgierski gość zwiedził muzeum Czartoryskich, a następnie złożył wizytę prof. Janowi Dąbrowskiemu i jego żonie. Ostatnim punktem programu był obiad wydany przez wojewodę Małaszyńskiego na cześć ministra Hómana. Wieczorem minister żegnany przez władze samorządowe i akademickie opuścił Kraków i wyruszył w drogę do Budapesztu. Do czeskiej granicy towarzyszył mu wiceminister B. Żongołłowicz ${ }^{58}$.

Rok 1935 był zatem szczególny dla polsko-zagranicznych kontaktów w dziedzinie oświaty i kultury. Trzech ministrów oświaty odwiedzających Polskę w konkretnych celach - podpisania umów kulturalnych i oceny ich realizacji - to dla ciągle odradzającej się, szukającej dobrych rozwiązań polskiej szkoły i polskiej nauki wydarzenia niezwykle istotne. Poza tym umacniające pozycję Polski na arenie międzynarodowej. Polski, która zyskiwała nowych sprzymierzeńców, nowych partnerów, również tych w zakresie kształtowania stosunków oświatowych.

\footnotetext{
57 Ibidem, s. 18.

58 Minister Hóman opuścił Kraków, „Czas” 1935, nr 309, s. 4.
} 
Analizując przebieg opisanych wizyt, trzeba zwrócić uwagę na kilka szczegółów. Program wizyt był podobny. Wszyscy trzej ministrowie odwiedzili Warszawę i Kraków. W Warszawie wszyscy składali wieńce na Grobie Nieznanego Żołnierza i odwiedzali Centralny Instytut Wychowania Fizycznego. W Krakowie zaś wizytowali Bibliotekę Jagiellońską i zwiedzali pobliską Wieliczkę. Ministrowie Szwecji i Węgier składali również hołd Marszałkowi Piłsudskiemu, którego ciało spoczywało w krypcie św. Leonarda na Wawelu i brali udział w usypywaniu kopca Piłsudskiego na Krakowskim Sowińcu. Minister Radew odwiedził Polskę jeszcze za życia Marszałka, aczkolwiek się z nim nie spotkał.

Kumulacja tych wizyty w jednym roku może świadczyć o tym, że Polska starała się umocnić w Europie, nawiązując różnego rodzaju formy współpracy z innymi państwami. Ważną rolę odgrywały także kwestie oświaty i kultury. Ministrowie oświaty z Bułgarii i Szwecji przybyli do Polski w celu zawarcia umów kulturalnych pomiędzy swoimi państwami a Rzeczpospolitą. Z kolei węgierski przedstawiciel resortu oświaty swoją wizytę poświęcił sprawdzeniu, jak przebiega realizacja podobnej umowy, którą Polska i Węgry podpisały rok wcześniej.

Powyższy artykuł ma również charakter kronikarski, stąd większa liczba cytatów i nazwisk, które być może nie wszystkim są znane. Takie podejście to tematu wynika między innymi z faktu, że nie zachowały się źródła archiwalne, a jeśli już to tylko cząstkowe, które mogłyby zobrazować przebieg owych wizyt, ważnych dla polskiej oświaty okresu II Rzeczypospolitej. 